\title{
PENINGKATAN KOEFISIEN PERPINDAHAN KALOR ALIRAN AIR MENGGUNAKAN GELEMBUNG UDARA
}

\author{
Sartono Putro \\ Jurusan Teknik Mesin Fakultas Teknik Universitas Muhammadiyah Surakarta \\ Jl. A. Yani Kotak Pos 1 Pabelan Surakarta \\ sartono_putro@ums.ac.id
}

\begin{abstract}
ABSTRAK
Peningkatan koefisien perpindahan kalor konveksi dapat dilakukan dengan memodifikasi permukaan saluran dengan pemasangan sirip. Adapun permasalahan yang ditimbulkan dalam modifikasi ini adalah kesulitan pabrikasi dan meningkatkan pressure drop. Perpindahan kalor dalam media aliran gas-cair banyak dijumpai dalam komponen-komponen sistem konversi energi. Perpindahan kalor yang terjadi ditentukan oleh koefisien perpindahan kalor yang dalam hal ini sangat dipengaruhi oleh hubungan kompleks antara properties fluida, dimensi dan permukaan pipa, serta pola aliran (flow pattern) dua fasa. Penelitian ini bertujuan untuk mengetahui hubungan perubahan debit air, debit udara dan fluks kalor terhadap koefisien perpindahan kalor.

Penelitian dilakukan dengan mengalirkan air dari atas dan udara dari bawah dalam bentuk aliran gelembung. Pipa uji terdiri atas pipa tembaga dengan $D_{i} 24 \mathrm{~mm}$ panjang $800 \mathrm{~mm}$ dililit dengan elemen pemanas listrik sepanjang pipa. Ujung atas dan bawah pipa uji disambung dengan pipa transparan untuk mengetahui pola aliran yang terjadi. Untuk mengukur temperatur dinding dipasang termokopel di dinding luar pada lima titik sepanjang pipa uji, sedangkan temperatur fluida diukur dengan memasang termokopel pada sumbu pipa di tujuh titik sepanjang pipa uji.

Hasil penelitian menunjukkan bahwa koefisien perpindahan kalor eksperimen meningkat dengan meningkatnya debit udara dan menurun dengan meningkatnya debit air. Koefisien perpindahan kalor eksperimen juga meningkat dengan meningkatnya fluks kalor listrik. Koefisien perpindahan kalor prediksi Chen maupun Ghajar memiliki harga yang jauh lebih kecil dibandingkan dengan hasil eksperimen. Kondisi penelitian berada pada: kualitas gas (x) 0,000058 sampai 0,000116, dan fraksi hampa (a) 0,0462 sampai 0,1021, serta fluks kalor listrik (q”)1627,189 W/m² sampai $11398,62 \mathrm{~W} / \mathrm{m}^{2}$.
\end{abstract}

Kata kunci : Perpindahan kalor, Koefisien, Dua fase, Aliran gelembung.

\section{PENDAHULUAN}

Penelitian-penelitian yang berhubungan dengan upaya mencari peningkatan koefisien perpindahan kalor terus dilakukan. Salah satu cara peningkatan koefisien perpindahan kalor yang banyak dilakukan adalah dengan me- modifikasi permukaan saluran baik permukaan luar maupun permukaan dalam. Modifikasi yang banyak dilakukan adalah dengan pemasangan sirip pada permukaan luar dan atau permukaan dalam saluran. Adapun permasalahan yang ditimbulkan dalam modifikasi pemasangan sirip 